\title{
Lorenzo Ghiberti and the Language of Praise
}

Describing the status of Lorenzo Ghiberti and Filippo Brunelleschi relative to their many colleagues at work on the cathedral of Santa Maria del Fiore in Florence in the early 1420s, Margaret Haines observes that, 'Their position was somewhat superior...reflecting their artistic and cultural expertise. ${ }^{11}$ Expectations of artists, how they were seen and the ways in which they saw themselves and each other in fifteenth-century Florence are often caught up in the idea of 'expertise'. However, quite what constituted 'expertise' is uncertain and hard to define.

A text like Ghiberti's Commentarii, from which it is possible to glean some sense of how he perceived his own expertise and that of his peers, is therefore a useful, if not invaluable tool. The second part of Ghiberti's text in particular is illuminating as to how he understood various types of 'expertise', how they might be acquired and to what useful end they had been put. The Commentarii, though, are themselves elusive of definition. Not only is the surviving text corrupt, but locating the metanarrative (assuming there is one) of a group of writings that includes elements of history, biography, autobiography, criticism, scientific treatise and commonplace book is difficult to say the least.

The accepted title of Ghiberti's writings comes not from the extant manuscript copy but from a reference to it in a nineteenth century work, Cicognara's Storia della scultura. ${ }^{2}$ Lorenzo Bartoli, in his 1998 edition of the texts, comments that, 'The Commentarii, in particular in the papers on perspective, have the form of a zibaldone and not of a treatise structured in three parts (or commentarii) as they have been interpreted by Schlosser. ${ }^{3}$ Bartoli goes on to point out that it is only in relation to the second part of his writings that Ghiberti himself uses the term commentario, preferring to refer to the first part, straightforwardly enough, as 'questo primo vilume.' The word Schlosser used,

This essay formed part of a seminar given in November 2014 as part of the Robert H Smith Renaissance Sculpture Programme at the Victoria and Albert Museum. I am grateful to Peta Motture and Lois Salter for their invitation to contribute to the programme.

${ }^{1}$ Margaret Haines, 'Ghiberti's Trip to Venice,' from Coming About...a Festschrift for John Shearman, Harvard University Art Museums, Cambridge, Mass., 2001, pp. 57-63, p. 57.

${ }^{2}$ Leopoldo Cicognara, Storia della scultura..., Giachetti, Prato, 1824, 8 vols., vol. 3, p. 167.

${ }^{3}$ Lorenzo Ghiberti, I Commentarii, Biblioteca nazionale centrale di Firenze, II, I, 333 Lorenzo Bartoli (ed.), Biblioteca della scienza italiana 17, Giunti, Florence, 1998, p. 15. 'I Commentarii, particolarmente nelle carte prospettiche, hanno dunque la forma di uno zibaldone e non quella di un trattato in tre parti (o commentarii) come lo aveva interpretato Schlosser.' My translation (unless stated otherwise, translations are taken from the Courtauld edition: The Commentaries of Lorenzo Ghiberti, Courtauld Institute of Art, London, 1949?). Whatever his reservations about the term, Bartoli's edition retains the word Commentarii as its title and for the sake of clarity the present study will do the same. 
denkwürdigkeiten, is no more helpful than commentarii or indeed zibaldone as a descriptor for all three sections of the writings, at least in the sense of 'memoirs', which was the one that Schlosser intended. ${ }^{4}$ If, however, the word is seen less as defining the specifically literary category of memoir and more generally as a description of 'things worth remembering' then it perhaps comes closer to embracing the scope of Ghiberti's writing.

This scope is wide, but Ghiberti's 'things worth remembering' appear to be directed towards a particular end; the provision of some sort of literary resource which will serve to enable painters and sculptors to avoid the twin pitfalls of being either unlettered or overreliant on theory. ${ }^{5}$ In the first section, 'Arte Antica', the material from Pliny and Vitruvius of which the book is largely comprised is parenthesised by statements that seem to underline this. Near the beginning, Ghiberti lists (in a quotation from Vitruvius) the liberal arts in which the sculptor or painter should be instructed and proficient. ${ }^{6}$ Then, in the penultimate paragraph, he relates how, 'In this first volume, I have explained the things which the sculptor, or rather the statue-maker, and the painter need to know in order to gain mastery. ${ }^{7}$ Ghiberti's object in writing and in his selection of material appears, therefore, to be explicitly didactic. Yet it also appears that he has not, in fact, done what he claims in that penultimate paragraph; for he certainly has not gone far in instructing his readers in 'all these liberal arts: grammar, geometry, philosophy, medicine, astrology, perspective, history, anatomy, theory of design and arithmetic. ${ }^{8}$

This apparent failure is not what it seems. Ghiberti himself is manifestly comfortable with the extant classical literature of art, insofar as it existed in vernacular translation, and he displays here a commensurate confidence in the abilities of his readers, assuming that his iteration of the liberal arts as the basis of the artist's intellectual life will be understood. His own assured familiarity with the idea implies an audience possessed of a similar literary grounding.

This ease in the literary world of his humanist friends provides a clue as to why, having set out his stall as a proponent of a classical curriculum for the education of artists, Ghiberti then spends so much time in the first part of the Commentarii, 'Arte Antica', not in

\footnotetext{
${ }^{4}$ See Julius von Schlosser, Lorenzo Ghibertis Denkwurdigkeiten (I Commentarii), 2 vols, Julius Bard, Berlin 1912.

${ }^{5}$ Ghiberti, as at note 3, Arte Antica II.3, p. 47.

${ }^{6}$ Ibid., Arte Antica, II.1, p. 46.

7 'in questo primo vilume ò explicato delle cose le quail bisogni essere amaestrato lo scultore ouero statuario e'l picture,' ibid., Arte Antica, IX.1, p. 81.

${ }^{8}$ 'Conviene che .llo scultore, etiamido el picture, sia amaestrato in tutte queste arte liberali: Gramatica, Geometria, Phylosophia, Medicina, Astrologia, Prospectiva, Istorico, Notomia, Teorica disegno, Arismetrica.' ibid, Arte Antica, II.1, p. 46.
} 
explication but in anecdote. Having acknowledged the importance of theory to the painter and sculptor, and demonstrated his familiarity with the literature relevant to their development as craftsmen, Ghiberti also intends to bring to his writing that which he as a leading artist is uniquely placed to provide: visual acuity, and critical engagement not with texts but with objects. In other words, this is where his unique expertise can be brought to bear on a field of activity in which his humanist friends were differently expert. This is not about Ghiberti's acceptance into a literary, intellectual elite, but in his offering to that elite a view that only he could illuminate.

Ghiberti's second section, 'Arte Moderna', in which he traces a history of art (or more properly, perhaps, a loose genealogy of artists) from Cimabue who, "held to the greek manner,' to himself, is the most original and opinionated of his three books. ${ }^{9}$ In contrast to the first and third books it does not rely on extended quotations from classical authors but essays something entirely new - not, as is often stressed, the generation for the first time of what we might describe as 'art history', but the use of history as a means to define what is good and desirable in both a work of art and in the personality of the artist. As a result, Ghiberti makes explicit the connection between the products of an artist's practice, his qualities as a person, and his reputation.

This connection, however, between the artist and his reputation was not, for Ghiberti, to be made through reading but through looking. In the first part of the Commentarii, the works are almost entirely lost, but the passages Ghiberti chooses from Pliny are primarily ekphrastic. ${ }^{10}$ In the third part, Ghiberti enlists Alhazen, Bacon, Witelo and Pecham in order to instruct his readers in the theories of optics and perspective and, as Lorenzo Bartoli points out, for the greater part of his work, Ghiberti 'confines himself to the gathering and combination of sources without modifying them at all."11 There is little or no critical engagement on Ghiberti's part with the material he collates. Nevertheless, in addition to the technical material he gathers from his various sources he does include anecdotes concerning, for example, the excavation and reception of antique sculpture. Buried in these anecdotes, which include descriptions of objects, are a number of illuminating moments in which, as in the 'Arte Antica' and 'Arte Moderna', he describes not

\footnotetext{
9 'tenea la maniera greca', ibid., Arte Moderna, p. 83.

${ }^{10}$ Included in the extract from the Courtauld Ghiberti published here is a bronze statue of Nero by Zenodorus (part 12; corresponding to VI.18 in Bartoli's edition). Ghiberti carefully notes the location of the surviving fragments in Rome: 'the head and one hand with the orb are today set up in Rome near the church of S. Giovanni in Laterano.'

11 'si limita a raccogliere le fonti ed a combinarle senza modificarle affatto.' Ghiberti, as at note 3, p. 15.
} 
works but people. The Marquess of Ferrara and an ancient, Sienese, Carthusian goldsmith called Fra Jacopo are described respectively as one who, 'delighted in painting and sculpture,' and 'a draughtsman who took great pleasure in the art of sculpture. ${ }^{12}$ The importance of this lies in the link the descriptions make between the third and the first two parts of the Commentarii. The questions of who looks (nobles, commoners, religious, the old), how they look (with delight and pleasure) and what they look at (antique and contemporary works) are as central here as throughout the other two books. Here are individuals whose accomplishments include the pleasure they take in art, and who are concerned not with the theory of it but with the business of looking carefully at it.

Still more significant in this regard is Ghiberti's discussion of Niccolo Niccoli and his chalcedony cameo. ${ }^{13}$ Niccolo's cameo is carefully described by Ghiberti, who, whilst he writes of its figure-carving in minute detail, also describes Niccolo's studiousness and his collection of rare antiquities. These are not kept hidden but shown to friends and others who might appreciate them, all of whom say how marvellous the cameo is. Their ability to comment on the cameo is based on three things: firstly their knowledge of the theory of art; secondly of its practice in keeping with the stipulations of the first commentary; and thirdly, their observation of the object in hand, in which they are able to discern 'tutte la misure e le proportioni debbe avere alcuna statua o scultura. ${ }^{14}$ It is knowledge allied to observation which enables judgement to be made, and it is in the way Ghiberti brings his own observation and knowledge to bear on the objects he describes in the second commentari that we can understand what qualities he regarded as important in a work of art and the person of an artist.

It is in 'Arte Moderna' that Ghiberti's own voice can be most distinctly heard as he undertakes a selective, critical appraisal of art in the period between the emergence of Giotto and his own time. By virtue of this selectivity, and the originality of his selections, drawn almost entirely from first hand knowledge, it is possible to discern in his writing something of Ghiberti's personal opinions, revealed in the words he chooses to describe artists and works with which he is personally familiar and to name the qualities Ghiberti

\footnotetext{
12 Ibid.,Commentari III, III. 2, p. 108.

${ }^{13}$ Ibid.,Commentari III, III. 3, p. 109. Ghiberti's interaction with antique objects, including the cameo, and the social aspects of looking are discussed in Lynn Catterson, 'Finding, Fixing and Faking in Ghiberti's Third Commentarii', in Sharon Gregory and Sally Anne Hickson (eds.), Inganno - The Art of Deception: Imitation, Reception and Deceit in Early Modern Art, Ashgate, Aldershot, 2012, pp. 123-149.

${ }^{14}$ Ibid.,Commentari II, III, p. 109. 'all the measure and proportion necessary in a statue or sculpture.' Courtauld translation modified.
} 
most admired in his predecessors; qualities to which it might not be unreasonable to believe that he himself aspired.

The translation of these qualities from literary topoi to practical observations of Ghiberti's approved manner of working, however, is fraught with difficulty. Ghiberti's prose is limited, repetitive and formulaic. ${ }^{15}$ Its very repetitiveness, though, enables the basis of an analysis to be established. Baxandall's idea that, 'Any language...is a conspiracy against experience in the sense of being a collective attempt to simplify and arrange experience into manageable parcels', is useful here. ${ }^{16}$ In the words Ghiberti uses again and again to describe and explain (or to simplify and arrange) his experiences, in particular the words he uses to praise his antecedents, both personally and for particular works, there is at least consistency in the way they represent opinion and experience. And from their repetition it is clear that they delineate a number of traits that Ghiberti felt were desirable, admirable or necessary in the character or hand of an artist. These are the traits, which it may be possible to gather up under the heading of 'expertise'.

Those categories of performance, manual and intellectual, which are now coded as 'expertise' were many, and Ghiberti's own language of praise suggests that possession of one was no guarantee of possession of another. In the three component parts of the Commentarii, 137 different words of approbation are used describe the qualities of objects and the individuals who made them. They are often repetitive (13 are derivative of egregio or eccellente) but there is value in their insistent repetition, which is sometimes diluted by translation, especially into English, whose rich vocabulary inclines us to seek variety where monotony is sometimes precisely the point.

Although Ghiberti deploys the same terms again and again, he does so in ways that embody subtle shifts and nuances of expression. Sometimes it is what an artist lacks that is telling. For example, an artist could be perito (skilled) or demonstrate arte (skill), without having ingegno (ingenuity, originality or talent). Equally, an artist who was docto (learned) might possess that quality in either the work of his hand or his mind, but not necessarily both. In 'Arte Moderna', Bonamicho is described as 'gifted by nature' (ebbe l'arte da natura) and 'most learned' (doctissimo), but neither he nor his work merit the term ingegno. Pietro

\footnotetext{
${ }^{15}$ Although, as Baxandall points out in Giotto and the Orators, Clarendon, Oxford, 1971, the gradual refinement of literary Latin towards its full subtlety and nuance was itself an ongoing and decidedly unfinished project in the hands of the humanists.

${ }^{16}$ Ibid., p. 44.
} 
Cavallini is skilled (perito) and more learned than (dottissimo infra) Bonamicho but, like him, does not possess or manifest ingegno. ${ }^{17}$

The overarching idea of 'mastery', magistero or maestero, might be applied to the exercise of one particular skill or the accumulation and exercise of a number. During work on the first set of baptistery doors, Ghiberti tells us he was paid an annual retainer of 200 florins by the Calimala, for his fatica e magistero, his overall control of the project as well as the work of his hand. ${ }^{18}$ In contrast, whilst Taddeo Gaddi was learned (docto) and a man of great ingegno, his mastery (maestero) was a quality imparted to a particular work, a panel painting for Santissima Annunziata, not a quality of his mind. ${ }^{19}$ In the whole of the 'Arte Moderna', only the two most praised and privileged artists, Ambrogio Lorenzetti and the mysterious Northern goldsmith, Master Gusmin, merit the fullest description of their 'expertise' as a function of their personality. Each is a maestro: docto, perito, full of ingegno and arte. $^{20}$

Of the words Ghiberti uses most commonly to denote his approval of a work or an artist, many fall into a category which at first glance might be described as simple praise. Grande, excellente, egregio and their various derivations and superlatives are among his most frequently used terms. Of these, grandissimo and excellentissimo appear in the notes on almost every one of the artists Ghiberti singles out, in relation to both their works and their persons. For an English translator this poses the problem of finding a variety of terms to provide the light and shade required by an English reader. Thus, for example, in the Courtauld translation, egregio and its derivatives become, variously, outstanding, excellent, magnificent, skilful, fine, of outstanding merit, clear, flourishing, notable, well executed, well done, gifted and beautiful. ${ }^{21}$ Whilst this makes for an English style which is at least readable, and is a valid effort at rendering some of the various facets of meaning with which Ghiberti may have intended to invest the term (though this supposition that there are untold facets of meaning in Ghiberti's writing is itself problematic), it at the same time loses the weight that Ghiberti's own text gradually acquires with repetition. It is in the repetition of terms that Ghiberti exposes not only his limitations as a prose stylist, but also those qualities of an

\footnotetext{
${ }^{17}$ Ghiberti, as at note 3, pp. Arte Moderna, II.viii and II.ix, pp. 86-7.

${ }^{18}$ Richard Krautheimer in collaboration with Trude Krautheimer-Hess, Lorenzo Ghiberti, Princeton University Press, Princeton, 1970, repr. with new preface 1982, p. 7.

${ }^{19}$ See Ghiberti, as at note 3, Arte Moderna, II.vi p. 85.

${ }^{20}$ For Lorenzetti see ibid, Arte Moderna, II.xi - II.xii, pp. 87-9. For Gusmin see ibid. Arte Moderna, II.xvii, pp. 90-1..

${ }^{21}$ All taken from the Courtauld edition. Note that the in the section of the translation published in this issue of the Sculpture Journal the words of praise discussed in this article have been added in the original Italian in square brackets in the relevant locations.
} 
artist or his work, and the ways of describing them, which he most values. Therefore, rather than seeking varietas in translation, a more fruitful approach to Ghiberti's language of praise might be to start by simply examining two types of word which crop up frequently and the uses to which Ghiberti puts them, without at first attempting fully to define them. ${ }^{22}$

The word egregio, as discussed above, takes on in Ghiberti's writing an apparently all-purpose role. Egregio and its derivatives appear in 'Arte Moderna' on 19 occasions, and feature in each paragraph of the work. However, its ubiquity is not as complete as it may seem. Of the 19 usages, only 5 relate to individuals, whilst 14 are in connection with particular works of art. Given the normative use of Egregio as a personal honorific, for instance in addressing letters, this reluctance to use the term as a descriptor for people seems surprising. ${ }^{23}$ Furthermore, whereas Ghiberti has no hesitation in ascribing numerous other qualities to his own work, he at no point uses egregio in relation to himself. Thus, against expectation, it might stand (as the most common of its type) at the head of a category of predominantly object related words which describe a quality which for some reason it would be immodest to ascribe to oneself or one's own work.

Perfetto appears to be a similar term. It appears 16 times, of which only 2 refer to individuals, Ambrogio Lorenzetti and Master Gusmin, rather than works. ${ }^{24}$ Again, there is a discernible reluctance on Ghiberti's part to use the term in relation to himself or his own oeuvre. He does so only once, and then, in the final paragraph of the Commentary, it is to describe not something he himself has done, but the rules he gives to colleagues for making work under his instruction. He assures the reader that he is able to ensure that work on which he advises will be executed with perfetta misura. ${ }^{25}$

If these two terms then stand at the head of the group of words Ghiberti uses to describe works, there are two which are similarly favoured in relation to people. These are perito and docto and their various derivatives. These words, whose associated terms might

\footnotetext{
${ }^{22}$ For other discusions of the semantic difficulties raised by translating words with the potential to bear more than a single meaning or for which a precise modern equivalent is elusive, see Stephen Perkinson, 'Engin and Artifice: Describing Creative Agency at the Court of France, ca. 1400', Gesta, Vol. 41, No. 1, Artistic Identity in the Late Middle Ages, 2002, pp. 51-67; Michele Tomasi, 'Entre "estat tenir" et "esbatement": I'orfèvrerie selon les chroniqueurs français sous les règnes de Charles $\mathrm{V}$ et Charles Vl', in Élizabeth Antoine-König and Michele Tomasi (eds.), Orfèvrerie gothique en Europe: production et reception, Études lausannois d'histoire de l'art, 21, Viella, Rome, 2016, pp. 125-142.

${ }^{23}$ For example, the letters from Ghiberti to Bartolommeo Cecchi, operaio of Siena Cathedral during the greater part of the construction of the font, without exception address Cecchi as egregio. The letters to his colleague and friend the goldsmith Giovanni Turini, on the other hand, do not. The letters are preserved in the Archivio dell'Opera della Metropolitana di Siena, Ms. 30 (formerly entitled Libro di Documenti Artistici).

${ }^{24}$ Ghiberti, as at note 3, Arte Moderna, II.xii, p. 88 and II.xvii, p. 91.

${ }^{25}$ Ibid., Arte Moderna VI.i, p. 97.
} 
loosely be grouped under the headings 'skill' and 'learning', appear respectively 11 and 20 times in 'Arte Moderna'. Perito is never associated with a particular object. There are three occasions on which the root doct- is applied to works, but in each case it is as a way of expressing approval of their maker.

The first instance relates to the production of Stefano, the first of Giotto's followers to be dealt with by Ghiberti, who is introduced as having been egregissimo dottore, 'outstandingly learned'. ${ }^{26}$ His works, later in the same paragraph, are described as fatte con grandissima doctrina, 'done with the greatest learning'. Here it is only in the broadest possible sense that 'learning' is being imputed to the work and it is of a painter who has already been established as himself having been learned.

The same is true of Taddeo Gaddi, whose person and work are similarly introduced. Taddeo is di mirabile ingegno... doctissimo maestro, 'of great invention [and] a most learned master. ${ }^{27}$ And his miracle of St Francis is 'fatta con tanta doctrina et arte, e con tanto ingegno...,' 'done with such learning and skill and with such ingenuity...' Here, as with Stefano's oeuvre, the work is used to define the man; it is done with learning, but it is the learning of the artist. It is the man who is full of doctrina.

This raises another, subsidiary, question about Ghiberti's attitude towards learning, which concerns both the kind of learning he valued and the way in which it was to be acquired. In 'Arte Antica', Ghiberti is emphatic that learning resides in both hand and mind. Whilst acknowledging that the principal means by which we can learn from the ancients is their writings, Ghiberti is equally sure not only that the purpose of such learning is practical; the study of classical writing will profit us 'as we seek to perfect our own new inventions. ${ }^{28}$ Furthermore, he goes on to point out the likely failings of those painters or sculptors who fail to grasp fully either the skill of the hand or the theory of their art. ${ }^{29}$ Neither will succeed: the unlettered being condemned to produce work without authority and the theoretician to make merely a shadow of the thing attempted.

These comments help to flesh out the compliment Ghiberti pays his predecessors in 'Arte Moderna'; their 'learned' work is the product neither of mere skill nor of great intellect alone, but both. In making this clear from the start, Ghiberti then sets himself not within an intellectual elite in which he aspires to membership but rather slightly outside or even above

\footnotetext{
${ }^{26}$ Ibid., Arte Moderna II.i, p. 85.

${ }^{27}$ Ibid., Arte Moderna Il.i, p. 85.

${ }^{28}$ Ibid., Arte Antica I.i., p. 45.

${ }^{29}$ Ibid., Arte Antica II.iii, p. 47.
} 
it, in a separate realm where the complementarity of hand and mind are expressed in work which comes to signify an ideal order of attainment in both understanding and manufacture.

That he intends to place himself and his own works within this ideal order of attainment becomes clear in the final part of the autobiographical section of 'Arte Moderna'. Here, as Bartoli points out, Ghiberti describes his work on the Gates of Paradise as 'condotta con grandissimo studio e disciplina, delle mie opere e la piu singulare opera ch'io abbia prodotta, e con ogni arte e misura et ingegno e stata finito. ${ }^{30}$ These are important words - study, discipline, singularity, skill, measure, originality - and Ghiberti's self-identification with such qualities, won not lightly but as the achievements of a lifetime's work, and described not randomly but with careful thought as to their implications, makes sense of the high regard in which Lorenzo clearly held himself. Even so, he does not ascribe to himself the quality of being docto. Perhaps he sought to place a little distance between the learning he manifested, to which his likely readers could never attain, and their more scholarly accomplishments.

The third instance of 'learning' being used in connection with a work of art, after Stefano and Taddeo Gaddi, is in Ghiberti's brief treatment of Duccio. Ghiberti describes the Maestà, as fatta molto excellentemente e doctamente, 'made most excellently and learnedly, ${ }^{31}$ Although the intention is again to imply learning on the part of the artist, there is also here a hint as to the criteria according to which Ghiberti was prepared to consider an artist 'learned.' Duccio, unlike Stefano and Taddeo, is not introduced as dottore or doctissimo, but with the observation that tenne la maniera greca, 'he held to the Greek manner. ${ }^{32}$ The only prior observation of this kind is of Cimabue, whose own biography is entirely subordinated to that of Giotto, but it is worth pursuing the difference between these two instances.

\footnotetext{
30 'It was done with the very greatest study and perseverance, so that it is the most remarkable of all the works I have ever produced; it is now finished with all skill, proportion, and resource.' Ibid., Arte Moderna, VI. i., p. 97. Bartoli's discussion of this is on p. 16. In the interests of showing how Ghiberti's Italian is rendered into English, the Courtauld translation given above, can be compared with those by Gilbert and Holt. Creighton Gilbert translates the passage as: 'Carried out with greatest study and discipline of my works, it is the most special work I have done, and it has been finished with every skill and proportion and talent.' Creighton Gilbert, Italian Art 1400-1500: Sources and Documents, Englewood Cliffs: PrenticeHall, 1980, p. 87. Elizabeth Holt gives 'Executed with the greatest study and perseverance, of all my work it is the most remarkable I have done and it was finished with skill, correct proportions, and understanding.' Elizabeth Gilmore Holt, Literary Sources of Art History: An Anthology of Texts from Theophilus to Goethe, Princeton: Princeton University Press, 1947, p. 163.

${ }^{31}$ Ghiberti, as at note 3, Arte Moderna III.i, p. 90.

${ }^{32}$ Ibid., Arte Moderna III.i, p. 90.
} 
Of Cimabue himself we learn only three things: that he found and apprenticed Giotto; that he was of distinguished appearance; and that he held to the Greek manner (and was famous for it). ${ }^{33}$ His role as mere Prologue to Giotto's starring role in the first act of 'Arte Moderna' is quite clear, and made the more so by the first comment Ghiberti makes concerning his distinguished pupil. In bringing in l'arte nuova, Giotto lasciò la rozeza de' Greci, 'left the crude manner of the Greeks.' This is in stark contrast to Duccio, who despite maintaining the Greek manner of which Ghiberti had previously been so dismissive, manages yet to be a 'most noble painter', whose work was 'made most excellently and learnedly (sapiently?)'. ${ }^{34}$ It is possible to infer from this that there is therefore no necessary connection between learning and the expression of a particular style. The Greek manner may be crude, but its exponent may still be learned.

The importance of this observation lies in the extent to which it both coincides with and diverges from the Ghiberti described by Krautheimer, which is to say the Ghiberti who has dominated scholarship for the past sixty years. In discussing Ghiberti's relationships with the Florentine humanists in whose circles he increasingly moved as his career progressed, Krautheimer makes clear his opinion that whilst never a true scholar, Ghiberti aspired to the scholarship he saw and admired in his contemporaries. 'Ghiberti', he suggests, 'was a humanist and scholar by ambition only. ${ }^{35}$ Even so, 'learning' was among the highest attributes he was able to ascribe to his artistic predecessors and his desire was not just to be learned, but to grant himself a learned descent. Thus, in the second Commentary, with its insistent repetition that the best of his predecessors were almost invariably docto, doctissimo or dottore and that they made work doctamente and of tanto doctrina, Ghiberti constructs a view of learning which valorises the learned artist and at the same time permits learning to be expressed not only in literary and other kinds of scholarship but in making objects of a variety of styles and media.

The learning Ghiberti so admired was no more bound by period than it was by school or medium. The temporal span of 'Arte Moderna' is long. From Cimabue's discovery of Giotto to the latter part of Ghiberti's own career is a matter of almost two centuries. But while art historians, starting with Vasari, have seen in that period the roots of the changes that came over the arts during the course of Ghiberti's own century, Ghiberti sees not a steady ascent towards a necessary end, but a line of practitioners, a relay perhaps, in

${ }^{33}$ Ibid., Arte Moderna I.ii, p. 83.

${ }^{34}$ The Courtauld translation of this passage uses the term 'sapiently'. This would appear to be an example of searching for an English term that renders Ghiberti's limited vernacular less repetitive than otherwise.

${ }^{35}$ Krautheimer, as at note 18, p.313. 
painting and sculpture, including himself, whose work is worthy of approbation and whose skill is founded in shared qualities of greatness, perfection and learning. From Cimabue onwards, all art is modern. This modernity is expressed less in its difference from the primitive and unskilled work of the Greeks as it is in its similarity to the now resurrected work of the ancients. Thus, Ghiberti's perception of his own time is not at the end but in the middle of something, a continuum of those whose learning and expertise enabled them to produce work that was bellissima, grandissima and molto egregio.

That Ghiberti should see himself in a continuum, rather than as the culmination of a teleological history as Michelangelo was for Vasari, is important because it goes to the issue of what the Commentarii actually are; not an ill-matched sequence of classical commonplace book, art history and technical manual, but something which uses all three of these genres, despite their difference in texture and level of completion, to do something else.

Though the language Ghiberti uses to praise other artists (and himself) adheres to a formula, the formula may not be the one most usually ascribed to Lorenzo as a kind of aspirant humanist and seeker after acceptance in mid-quattrocento Florentine intellectual circles. The discussion of each artist and his works can be read not simply an abbreviated encomium but as something more practical, a kind of manual for knowing what is good and/or worthy of fixed, diligent looking. Since there is very little descriptive detail to be gleaned about individual objects from what Ghiberti writes, what seems to emerge instead is a sort of catalogue of ideal works, knowledge of which, and of the nature of their excellence, can act as a spur to the efforts of the artist to become better, more learned and perfect in the things he himself makes.

Through the Commentarii, Ghiberti moves the reader successively from a gallery of entirely (or almost entirely) lost works made by an idealised community of artists working in the distant past, whose oeuvre is accessible solely through the imagination, to a gallery of extant objects, many of which would have been familiar to a visually literate reader. Nevertheless, the contents of this gallery are also unlikely to have been seen at first hand in their entirety by more than a handful of contemporary individuals. Indeed, even Ghiberti himself had not encountered all the works of which he writes: the gold altar made for Louis of Anjou by Master Gusmin, for example, had already most likely been melted down to pay for Louis' Neapolitan military adventures by the time of Ghiberti's early youth. This being the case, it is possible to place a different construction on the first two parts of the Commentarii than that of a simple (or even a complex) history. Might Ghiberti not be encouraging the process of first constructing and then populating a type of musée 
imaginaire, similar to his own, an imaginative resource for an artist or spectator to draw on in attempting to understand and value the paintings and sculpture they might encounter or seek to create?

This approach to the first two commentarii then makes possible a more satisfying reading of the third. Instead of being an agglomeration of theoretical texts collected, magpie-fashion, by an artist whose inclination was more towards making than explaining but who nevertheless wished both to be and be seen to be conversant with the science of his art, the third part of the Commentari becomes the skeleton of a work which will provide the practical means by which the imaginative constructions of the first two can be emulated: imagination and experience enriched and enabled by knowledge. Looking fixedly thus becomes an activity to be directed both inwardly and outwardly in the service of making. In writing in the vernacular, Ghiberti makes available to the literate non-latinist what would otherwise be arcane, abstruse and inaccessible, whilst at the same time doing so in a format that valorises, through its utter dependence on them, the texts it sought to liberate from arcanity. This Ghiberti shares with the tradition of vernacular writing and preaching typified by the Pisan, Simone da Cascina; he seeks to provide a window through which his readers can see an otherwise closed world and to encourage them to look as hard as they can through it in order to know, understand and experience more of it.

The unfinished nature of Ghiberti's third commentary lends it the appearance of a rather desiccated and sterile incursion into territory with whose complexity even Ghiberti himself was struggling. A finished version, even one still in essence a series of extracts and quotations might have served a purpose more clearly connected to the first two; a practical manual for the proper understanding and emulation of the kinds of work the reader has been visualising from his reading of Ghiberti's history. The three parts of the Commentaries thus fall together much more cogently than is sometimes allowed, into a book about looking.

From the first Commentary we learn why we look, from the second what we should look at and from the unfinished third how we look. And from Ghiberti's own predilection for looking at the work of his peers and predecessors we can propose that just as the purpose of a text about spiritual vision such as Simone da Cascina's is to facilitate the re-making of the soul after the model of its protagonist, so the purpose of a book about looking is to facilitate making also - the making of art to match the figurae its author has encouraged his readers to observe and remember, using an expertise which has been defined for them by one who already possesses it. 
Lorenzo Ghiberti and the Language of Praise; Sculpture Journal 